\title{
Social Movement at Indonesia - Malaysia Border (A Case Study of Indonesian Migrant Workers' Education in Sebatik Island, a Land Border of Indonesia - Malaysia)
}

\author{
Hardi Warsono ${ }^{1 . *}$, Herbasuki Nurcahyanto ${ }^{1}$, and Thalita Rifda Khaerani ${ }^{1}$ \\ ${ }^{1}$ Public Administration Departement, Faculty of Social Science and Political Science, Universitas Diponegoro, Indonesia
}

\begin{abstract}
The condition of the state border area between Indonesia and Malaysia is totally different. Children of Indonesian Workers (TKI) have no (limited) access to learn in formal schools since they do not have citizenship documents. This study aims to analyze the implementation of basic education mission in the border area, particularly in Sebatik island, Nunukan regency, North Kalimantan province. In addition, the research was conducted using qualitative explorative approach. Problems arising at the border area are very diverse and systemic. The Indonesian government conducts the education in border areas still very limitedly. The role of the public, corporate and private companies (Three Net Working) becomes very important in operating the schools in border area. The role of a former lecturer who is famously called Mrs. Midwife Suraidah is very dominant in helping TKI's children to learn a variety of knowledge in Sekolah Tapal Batas (Tapal Batas School) in Sebatik island, Nunukan Regency, North Kalimantan province. Some help from companies such as Pertamina (national oil mining company), Dompet Dhuafa foundation and volunteers who are willing to be teachers strongly support the continuously of Tapal Batas School. The continuity of basic education in the state border becomes a challenge for the government since the purpose of the country written in the opening of Constitution 1945 is the intellectual life of the nation can be realized by implementing it in Nawacita program.
\end{abstract}

Keywords: Mission; Education; Border.

\section{Introduction}

The Tapal Batas School is one of education institution which give an basic education in the State border of Malaysia - Indonesia. The existence of Tapal Batas School in Middle Sebatik sub-district cannot be separated from a woman who is an early retired lecturer of Hasanuddin University, Makassar, Mrs. midwife $\mathrm{Hj}$. Suraidah. A tireless and sincere struggle has led her to Sebatik island by establishing Tapal Batas School of Sebatik Tengah, Nunukan Regency, North Kalimantan, Indonesia.

Tapal Batas School is an educational medium intended to accommodate IMW/TKI's children who do not have access for education in both Malaysia and Indonesia due to the absence of legal citizenship documents. Mrs. midwife Suraidah is strongly obsessed to achieve the condition in which no more Indonesian citizens work in Malaysia. Accordingly, they can easily attend school for a better future.

The quality of life can be influenced by various aspects such as the physical condition of the individual, psychological, the level of independence, and the social relations of individuals with their environment. For that reason, the environment in a region will have a direct impact on the quality of education of children in the area[6]. Also the CSR, it's not all about environmental goals but also sustainable development. Both can relate to create good and healthy environment.

Social movements can be defined as "collective behavior marked by mutual interest and long-term goals, i.e. to change or maintain public or institutions within. Another characteristic of social movement is the use of different ways out of the existing institutions"[1]. Anthony Giddens stated that "Social movement is a collective effort to pursue a shared interest or movement to achieve common goals through collective action outside the scope of the established institutions"[2].

Social movement can be regarded as a collective action to achieve the desire that become common goal. One of social movement embodiments is Education for All which is the mandate of the Constitution and the Law on National Education System. The existence of Tapal Batas School embodies Education for All (EFA) movement. As a social movement which can be interpreted as a social alliance to promote an aspect of social change in a society, specifically in education. The condition of Indonesian Migrant Workers (IMW/TKI)' children who cannot attend school becomes the stimulus for the establishment of Tapal Batas School. EFA as a social movement gained so much support from various institutions/parties that it can survive and grow until today. The ability to collaborate with various parties is

\footnotetext{
* Corresponding author: hardie wsn@yahoo.com
} 
an important requirement for the continuity of Tapal Batas School.

Border area until today (2017) is still so identical to "limitations" that almost all border areas in Indonesia have the same problem, i.e. wealth difference of the people in the border area as a result of limitation in a variety of basic infrastructure, educational issues, health problems as well as economic social problem faced by the people/community who are still highly dependent on neighboring country (Malaysia). The condition of IMW's children who have to walk tens of kilometers is a testament to their persistence, enthusiasm and fighting power to be able to study at Tapal Batas School. The conditions of nature and other obstacles obviously do not dampen their passion for school.

It is a woman named Suraidah whose a sincere dedication to live her life to accommodate and educate IMW's children. Her thought could not accept the facts about the children who did not go to school. It was not because they do not have the spirit for school, but because of the lack of berths to gain the knowledge. Her dream to educate Indonesian's children within the limitations is eventually accomplished and was finally able to establish a school with some help from many parties. At first, Suraidah offered herself to be their "day care" when their parents are working. Gradually, the kids were guided and treated to various lessons. As more and more people are getting around for her day care, Suraidah then strongly determined to set up a school in the land border between Indonesia - Malaysia is indeed intended for IMW's children working in Malaysian plantations.

Collaboration with third parties is greatly necessary in realizing the continuity of Tapal Batas School. Local Government of Nunukan regency, Pertamina EP Tarakan Field, Dompet Dhuafa Foundation and volunteers as well as the surrounding community who want to help the operation of Tapal Batas School. Each party has played its own important role in supporting Tapal Batas School. The existence of social media such as Facebook, Twiter, Whatsapp, Youtube, and so on becomes a helpful medium to introduce Tapal Batas School to the world. Consequently, there will be a lot of people who want to share and contribute to Tapal Batas School

\section{Methodology}

This research was conducted with qualitative approach. Data were collected by in-depth interviews related to the history of pioneering border education movement. It was the parents who appointed the key informant that was midwife Suraidah who pioneered informal education activity which then got support from society, entrepreneur, non goverment organization and the government continued to focus group discussions on the future of the movement.

\section{Discussion}

Stages of the emergence of state border educational movement refers to Horton and Hunt which includes discomfort, stimulation, formalization and institutionalization stages[3]. This educational movement eventually led to Tapal Batas School Boundary which has been a collaboration of various parties, the Government, the communities and companies through Corporate Social Responsibility (CSR) aid.

A "corporate social initiative" is broadly defined as " an initiative by which a firm engages in actions that appear to furthersome social good, beyond the interests of the firm and that which is required by law' [4]. The word "social" is used loosely here, as social initiatives can address a variety of issues, including but not limited to diversity, community development, promotion of education, labor standards, or environmental protection[4]. Much of the literature mentions such initiatives simply as Corporate Social Responsibility /CSR.

Pertamina's aid by CSR, Dompet Dhuafa foundation and communities are such forms of concern for Tapal Batas School, which is an embodiment of EFA, educational movement for all. EFA as a social movement can be defined as "coalitions that engage in sustained action to promote ideas and preferences for changing prominent social, cultural and business practices"[4]. EFA is an international initiative first launched in 1990 to bring the benefits of education to "every citizen in every society." To realize this aim, a broad coalition of national governments, civil society groups, and development agencies such as UNESCO and the World Bank Group committed to achieving six specific education goals[5]:

1. Expand and improve comprehensive early childhood care and education, especially for the most vulnerable and disadvantaged children.

2. Ensure that by 2015 all children, particularly girls, those in difficult circumstances, and those belonging to ethnic minorities, have access to and complete, free, and compulsory primary education of good quality.

3. Ensure that the learning needs of all young people and adults are met through equitable access to appropriate learning and life-skills programs.

4. Achieve a $50 \%$ improvement in adult literacy by 2015 , especially for women, and equitable access to basic and continuing education for all adults.

5. Eliminate gender disparities in primary and secondary education by 2005 , and achieve gender equality in education by 2015 , with a focus on ensuring girls' full and equal access to and achievement in basic education of good quality.

6. Improve all aspects of the quality of education and ensure the excellence of all so that recognized and measurable learning outcomes are achieved by all, especially in literacy, numeracy and essential life skills.

Goals listed in World Bank document have not been fully realized yet. However, the efforts made by Mrs. Suraidah has at least given a little hope to IMW's children who live in the land border of Indonesia Malaysia in order to gain a wide range of knowledge and also to increase their sense of nationalism. They are IMW's children who do not have citizenship documents but can attend in Tapal Batas School. 


\section{Conclusion}

Education For All Movement is a must for the government, communities, and companies. Cooperation among these three components can be called Three Networking. EFA cannot be done only by the government, but corporate, public and private assistance are also needed to support the continuity of Tapal Batas School. The government should immediately be able to realize Nawacita program, i.e. to build Indonesia from the land border/peripheral area by strengthening these areas and villages in the framework of Indonesia as a unitary state and by improving the life quality of Indonesian people by increasing the quality of education. Residential document Problems (citizenship) must be resolved in so highly selective and prudent way that it will not cause uncontrolled public turbulence and dynamics.

\section{References and Notes}

1. K. Sunarto, Pengantar Sosiologi (Edisi Revisi), FEUI, Jakarta (2004).

2. F. Putra et al, Gerakan Sosial, Averrors Press, Malang (2006).

3. P. B. Horton, and C. L. Hunt, Sosiologi Jilid 2, terjemahan Aminudin Ram, Jakarta, Erlangga (2003).

4. P. Georgallis, The Link Between Social Movements and Corporate Social Initiatives: Toward a Multi-level Theory, J Bus Ethics (2017) 142:735-751DOI 10.1007/s10551016-3111-0 (2017).

5. World Bank, Education for All, Retrieved from www.worldbank.com on October 3, (2017).

6. Adi Fahrudin, Pengantar Kesejahteraan Sosial, Bandung, Refika Aditama (2012) 